\title{
Role of Melatonin in Temperature-Induced Activation of the Neuroendocrine Reproductive Axis in Garter Snakes
}

\author{
Treven J. Winters Stephanie Martin Holden Anderson Nichole D. Procter \\ Deborah I. Lutterschmidt
}

Department of Biology, Portland State University, Portland, OR, USA

\begin{abstract}
Keywords
Gonadotropin-releasing hormone $\cdot$ Thyroid-stimulating hormone · Thyrotropin - Deiodinase · Seasonal reproduction - Winter dormancy · Courtship behavior
\end{abstract}

\begin{abstract}
An animal's ability to respond optimally to changing environmental conditions is paramount to successfully reproducing and thus maximizing fitness. Studies on photoperiod-induced changes in neural thyroid hormone metabolism have conclusively linked environmental cues to the neuroendocrine reproductive axis of birds and mammals. Whether this conserved mechanism also transduces changes in environmental temperature, however, has not been fully addressed. We investigated whether the hormone melatonin mediates the effects of low-temperature dormancy on thyroid hormone metabolism within the hypothalamus of redsided garter snakes (Thamnophis sirtalis parietalis). To address this question, we used immunohistochemistry to assess changes in thyroid-stimulating hormone (TSH) in the infundibulum of the pituitary and deiodinase 3 (Dio3) and gonadotropin-releasing hormone $(\mathrm{GnRH})$ in the hypothalamus. We also asked if changes in TSH, Dio3, and/or GnRH immunoreactivity are associated with changes in male court-
\end{abstract}

ship behavior. In contrast to our predictions, 6 weeks of dormancy at $4^{\circ} \mathrm{C}$ significantly decreased the number of TSH-labeled cells in the infundibulum. It is possible that the observed decrease in TSH is related to the release of snakes from temperature refractoriness, but this idea needs further testing. Treatment of snakes with the melatonin precursor 5 -hydroxytryptophan during dormancy at $4^{\circ} \mathrm{C}$ both reversed the temperature-induced change in TSH immunoreactivity and disrupted the temporal pattern of male courtship behavior. These results suggest that TSH cells within the infundibulum are both modulated by temperature and sensitive to changes in melatonin. As predicted, male snakes hibernated at an elevated temperature of $12^{\circ} \mathrm{C}$ for 6 weeks and treated with vehicle showed no change in TSH-, Dio3-, or GnRH-immunoreactive cell number. Treatment of snakes with the melatonin receptor antagonist luzindole was not sufficient in rescuing the effects of dormancy at $12^{\circ} \mathrm{C}$ on TSH immunoreactivity or courtship behavior. However, luzindole-treated snakes showed a significant increase in $\mathrm{GnRH}$ immunoreactive cell number, suggesting that melatonin exerts an inhibitory effect on GnRH in garter snakes. In summary, our results provide critical insights into the mechanisms that mediate the effects of temperature on reproductive physiology and behavior.

(c) 2022 The Author(s).

Published by S. Karger AG, Basel
Karger@karger.com www.karger.com/bbe

Karger $\stackrel{\text { ' }}{=}$

BOPEN ACCESS
(C) 2022 The Author(s)

Published by S. Karger AG, Basel

This is an Open Access article licensed under the Creative Common Attribution-NonCommercial-4.0 International License (CC BY-NC) (http://www.karger.com/Services/OpenAccessLicense), applicable to the online version of the article only. Usage and distribution for commercial purposes requires written permission.
Correspondence to:

Deborah I. Lutterschmidt, dil@uci.edu 


\section{Introduction}

Reproduction is energetically expensive, and animals cannot afford to expend resources at nonbeneficial times. Correctly timing life-history events requires that an animal properly adjust its physiology, behavior, and morphology to the environmental conditions in which survival and reproductive success are maximized. These adjustments are induced through the effects of environmental cues on the brain and associated changes in hormones and behavior. It is now well established, for example, that seasonal changes in photoperiod alter the metabolism of thyroid hormones within the brain, which in turn mediates seasonal changes in the neuroendocrine reproductive axis (reviewed by [Nakane and Yoshimura, 2019]). In spring-breeding birds and mammals, the effects of lengthening days manifest as an increase in thyrotropin or thyroid-stimulating hormone (TSH) specifically within the pars tuberalis, a region of the anterior pituitary that surrounds the hypophyseal stalk [Hanon et al., 2008; Nakao et al., 2008a; Unfried et al., 2009]. TSH acts retrogradely on the hypothalamus to increase deiodinase 2 (Dio2) expression, while decreasing deiodinase 3 (Dio3) expression within the tanycytes lining the third ventricle [Yamamura et al., 2006; Nakao et al., 2008a, b; Yasuo et al., 2009]. The Dio2 enzyme converts thyroxine $\left(T_{4}\right)$ to bioactive triiodothyronine $\left(\mathrm{T}_{3}\right)$, whereas Dio3 inactivates $\mathrm{T}_{3}$ via deiodination [Yasuo et al., 2005]. These reciprocal changes in deiodinase activity work in concert to favor the accumulation of $\mathrm{T}_{3}$ within the hypothalamus [Yasuo et al., 2006]. Finally, the local accumulation of $\mathrm{T}_{3}$ facilitates remodeling of the tanycytes and an increase in the expression, synthesis, and/or release of gonadotropin-releasing hormone $(\mathrm{GnRH})$ [Yamamura et al., 2006; Perfito et al., 2012]. In this way, seasonal changes in photoperiod are relayed directly to GnRH neurons within the hypothalamus, which then modulate the activity of the anterior pituitary and gonads (i.e., the HPG axis) to modify reproductive physiology and behavior.

While many aspects of this neuroendocrine cascade are remarkably conserved across the vertebrates studied thus far [e.g., Wood and Loudon, 2014], the role of melatonin in mediating changes in TSH within the pars tuberalis differs between birds and mammals. The mammalian pars tuberalis has a high density of melatonin receptor type 1a [Weaver and Reppert, 1990; Dardente, 2007], and photoperiod-induced changes in melatonin directly modulate pars tuberalis thyrotropin [Hanon et al., 2008;
Ono et al., 2008; Unfried et al., 2009]. In contrast, the mechanisms transducing photoperiod information in birds are fundamentally different [Nakao et al., 2008a], as the avian pars tuberalis does not express melatonin receptors [Morgan and Williams, 1996]. Thus, while photoperiod-induced breeding in birds is also associated with increased thyrotropin in the pars tuberalis [Nakao et al., 2008a], these long-day changes are not directly regulated by melatonin signaling [Juss et al., 1993; Ball and Ketterson, 2008].

The role of this pathway in integrating other environmental cues has not been fully explored, and the lack of any studies in amphibians and reptiles, which are heavily influenced by seasonal changes in environmental temperature, is a notable gap in the comparative analysis of this pathway. A striking similarity between photoperiodand temperature-activated reproduction is that both involve cues (long days and cold temperatures, respectively) that decrease melatonin signaling (Fig. 1; reviewed in [Lutterschmidt, 2012]). In the current study, we asked if low-temperature dormancy alters thyroid hormone metabolism within the hypothalamus. We used the wellstudied red-sided garter snake (Thamnophis sirtalis parietalis) to address this question. Northern populations of red-sided garter snakes spend up to 8 months each year in underground hibernacula, with males first emerging in late April and females typically following suit 1-2 weeks later. The mating season is very attenuated, lasting only 4-5 weeks before snakes migrate away from the den to summer feeding grounds.

Seasonal changes in the expression of reproductive behavior are regulated exclusively by temperature in red-sided garter snakes [Whittier et al., 1987]. In addition, northern populations of red-sided garter snakes exhibit a temporally dissociated reproductive pattern, in which peak sex steroid hormone production and gametogenesis do not occur at the same time as mating behavior [Crews et al., 1984]. However, mounting evidence indicates that reproductive hormones may play a trans-seasonal role in facilitating changes in reproductive behavior. For example, prolonged low-temperature dormancy alters the number and size of GnRH-labeled neurons in the brain, plasma concentrations of sex steroid hormones, and male courtship behavior (see review in Lutterschmidt [2012]; [Lutterschmidt et al., 2022]). Previous studies also demonstrate that lowtemperature dormancy alters plasma melatonin concentrations of snakes [Lutterschmidt, 2012]. Therefore, we asked if temperature-induced changes in the melatonin signal mediate subsequent changes in the neuro- 
Photoperiod-Induced Reproduction in Spring-breeding Mammals

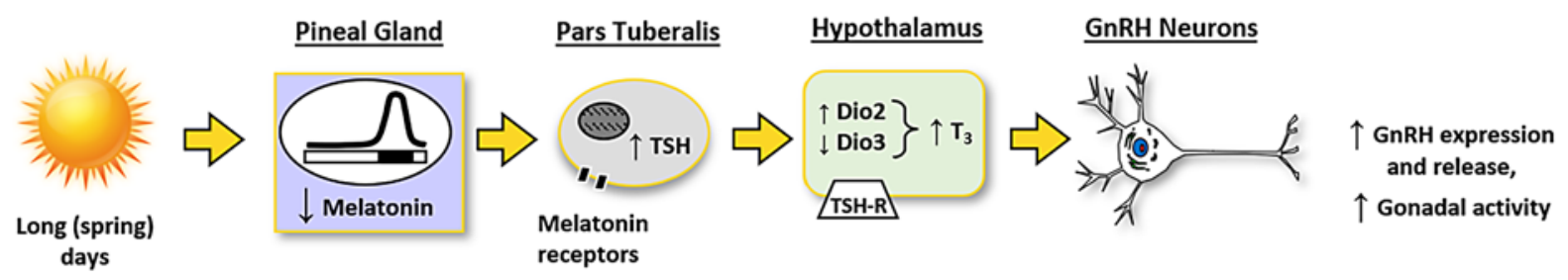

a

Temperature-Induced Reproduction in Garter Snakes

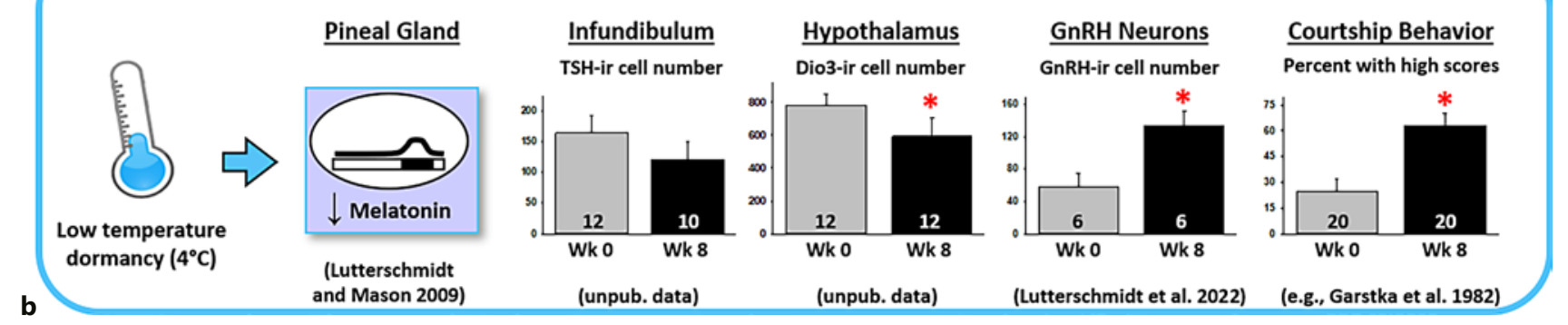

Fig. 1. a Schematic showing the effects of seasonal changes in photoperiod on neural thyroid hormone metabolism and gonadotropinreleasing hormone $(\mathrm{GnRH})$ in spring-breeding mammals. Long days decrease the duration of elevated melatonin concentrations and this in turn increases the synthesis of thyroid-stimulating hormone (TSH) within cells of the pituitary pars tuberalis. TSH acts retrogradely on the hypothalamus to alter the expression of deiodinases (Dio); reciprocal changes in Dio2 and Dio3 allow triiodothyronine $\left(\mathrm{T}_{3}\right)$ to accumulate within the hypothalamus, resulting in increased expression of $\mathrm{GnRH}$ and an activation of the reproductive axis. b In garter snakes, low-temperature dormancy similarly decreases melatonin concentrations and increases both GnRH immunoreactivity and courtship be-

endocrine reproductive axis (i.e., GnRH and thyroid hormone metabolism within the hypothalamus and/or TSH in the infundibulum of the pituitary gland; Fig. 1). We predicted that dormancy at $4^{\circ} \mathrm{C}$ would increase TSH, decrease Dio3, and increase GnRH immunoreactivity, and that elevated melatonin concentrations would reverse these effects. Similarly, we predicted that dormancy at an elevated temperature of $12^{\circ} \mathrm{C}$ would result in no changes in immunoreactive staining, but simultaneous inhibition of melatonin signaling via treatment with a melatonin receptor antagonist would increase TSH, decrease Dio3, and increase GnRH immunoreactivity. Such results would indicate that decreased melatonin concentrations in response to lowtemperature dormancy are both necessary and sufficient to activate the reproductive axis.

Melatonin and Temperature-Induced

Changes in the Reproductive Axis havior. Based on these results and additional pilot data for TSH and Dio3, we predicted that (1) increasing melatonin synthesis with the precursor 5-hydroxytrptophan would block the effects of low-temperature dormancy $\left(4^{\circ} \mathrm{C}\right)$ on TSH, Dio3, GnRH, and courtship behavior. Similarly, we predicted that (2) inhibiting melatonin signaling with the melatonin receptor antagonist luzindole would mimic exposure to $4^{\circ} \mathrm{C}$ and override the inhibitory effects of an elevated dormancy temperature $\left(12^{\circ} \mathrm{C}\right)$. Data shown in bar graphs are the mean +1 SEM; sample sizes are shown along the $x$-axes. Significant changes in Dio3-labeled cell number $(p=0.023)$, GnRH-labeled cell number ( $p=0.026)$, and courtship behavior [Garstka et al., 1982] following 8 weeks of dormancy at $4^{\circ} \mathrm{C}$ are indicated by asterisks.

\section{Materials and Methods}

Experimental protocols were approved by the Portland State University Animal Care and Use Committee and were in compliance with guidelines established by the National Institutes of Health Guide for the Care and Use of Laboratory Animals. This research was performed under the authority of Wildlife Scientific Permit WB18801 issued by the Manitoba Department of Sustainable Development.

\section{Experimental Design}

Snakes were collected from a den site in Inwood, MB, Canada, during the spring mating season and fall pre-hibernation period. Snakes were transported to the lab at Portland State University, where they were acclimatized to the photoperiod and temperature conditions shown in Table 1. Northern populations of red-sided garter snakes hibernate in underground dens for approximately 8 months each year. Both male and female snakes are refractory to warm temperatures, and previous studies indicate that significant 
Table 1. Acclimatization regimes for investigating the influence of melatonin manipulation on the reproductive axis of red-sided garter snakes (Thamnophis sirtalis parietalis) hibernated at different temperatures

\begin{tabular}{lll}
\hline "Season" & Dates & $\begin{array}{l}\text { Acclimatization conditions } \\
\text { (photoperiod; thermoperiod) }\end{array}$ \\
\hline Summer (feeding) & 24 May to 15 Aug & $16: 8 \mathrm{~h} \mathrm{~L}: \mathrm{D} ; 23: 18^{\circ} \mathrm{C}$ \\
Summer (feeding) & 16 Aug to 03 Sept & $14: 10 \mathrm{~h} \mathrm{L:D} ; 20: 16^{\circ} \mathrm{C}$ \\
Summer (feeding) & 04 Sept to 19 Sept & $13: 11 \mathrm{~h} \mathrm{L:D} ; 20: 12^{\circ} \mathrm{C}$ \\
Fall pre-hibernation & 20 Sept to 03 Oct & $12: 12 \mathrm{~h} \mathrm{L:D} ; 16: 12^{\circ} \mathrm{C}$ \\
Fall pre-hibernation & 04 Oct to 17 Oct & $11: 13 \mathrm{~h} \mathrm{L:D} ; 14: 12^{\circ} \mathrm{C}$ \\
Hibernation & 18 Oct to 29 Nov & $0: 24 \mathrm{~h} \mathrm{L:D} ;$ either $4^{\circ} \mathrm{C}$ or $12^{\circ} \mathrm{C}$ \\
Emergence (mating) & 30 Nov to 30 Dec & $16: 8 \mathrm{~h} \mathrm{L:D} ; 25: 15^{\circ} \mathrm{C}$ \\
\hline
\end{tabular}

changes in hormones and behavior occur within 3-8 weeks of exposure to low-temperature dormancy [e.g., Garstka et al., 1982; Bona-Gallo and Licht, 1983; Lutterschmidt and Mason, 2009; Lutterschmidt et al., 2022].

The experimental design employed in this study closely replicates that of previous studies and simulates the environmental conditions experienced by red-sided garter snakes under natural field conditions [e.g., Lutterschmidt et al., 2006]. In independent studies, we first determined the effects of low-temperature dormancy at $4^{\circ}$ on TSH-, Dio3-, and GnRH-labeled cells within the infundibulum and brain of untreated and unmanipulated garter snakes over time (Fig. 1b). Based on these data, we then asked if the effects of prolonged exposure to $4^{\circ} \mathrm{C}$ (i.e., significantly decreased Dio3 and increased $\mathrm{GnRH}$ ) are mediated by the hormone melatonin. To address this question, animals were randomly assigned to one of five groups (Fig. 2): a pre-hibernation group that was used to establish a fall baseline level of immunoreactive cells prior to manipulating temperature and melatonin $(n=12)$, hibernation at $4^{\circ} \mathrm{C}$ for 6 weeks and treatment with vehicle $(n=30)$ or the melatonin precursor 5 -hydroxytryptophan $(n=30)$, or hibernation at $12^{\circ} \mathrm{C}$ for 6 weeks and treatment with vehicle $(n=30)$ or the melatonin receptor antagonist luzindole $(n=30)$. Within each hibernation treatment group, snakes were further divided into two subgroups to determine the influence of treatment on immunoreactive cell number in the brain $(n=12)$ or courtship behavior $(n=18)$.

Hibernation was simulated by decreasing the ambient temperature in complete darkness (i.e., 0:24 h L:D photoperiod). The temperature regimes were chosen based upon previous laboratory studies in this species [e.g., Bona-Gallo and Licht, 1983; Krohmer and Crews, 1987; Whittier et al., 1987; Lutterschmidt and Mason, 2008,2009 ] as well as recorded body temperatures of red-sided garter snakes during winter dormancy under natural field conditions [Lutterschmidt et al., 2006]. The elevated temperature treatment, consisting of a constant temperature of $12^{\circ} \mathrm{C}$ during dormancy, was chosen because this temperature is significantly higher than the minimal body temperatures of red-sided garter snakes recorded during winter dormancy in the field but low enough to prevent dramatic changes in body condition (in the absence of feeding) during these prolonged experiments [Lutterschmidt and Mason, 2009].

\section{Hormone Treatments}

Previous studies showed that low-temperature dormancy decreases plasma melatonin concentrations in garter snakes [Lutterschmidt and Mason, 2008, 2009]. In an effort to reverse this effect and elevate melatonin synthesis during hibernation, we injected animals hibernated at $4^{\circ} \mathrm{C}$ with 5 -hydroxytryptophan (product number F4150, Bachem Americas, Inc., Torrance, CA, USA), a precursor to melatonin synthesis. We chose to manipulate plasma levels of melatonin via a precursor because direct, prolonged manipulations of melatonin rarely mimic endogenous melatonin rhythms and often produce inconclusive results, both in garter snakes and in other species (e.g., see reviews in [Lutterschmidt et al., 2003; Lutterschmidt, 2012]. In contrast, experimentally elevated levels of a precursor allow more melatonin to be synthesized within the animal according to natural circadian rhythms in enzyme synthesis and activity, and Lutterschmidt and Mason [2010] demonstrated that treatment of snakes with 5-hydroxytryptophan significantly elevates plasma melatonin concentrations. As in this previous study, we treated snakes with $1.2 \mathrm{mg}$ of 5-hydroxytryptophan diluted in $100 \mu \mathrm{L}$ of $10 \%$ ethanol in reptilian Ringer's solution. Control treatments consisted of the vehicle only (i.e., $100 \mu \mathrm{L}$ of $10 \%$ ethanol in reptilian Ringer's solution). Treatments were administered via intraperitoneal injection every 3 days for the entire hibernation period.

Similarly, we sought to inhibit melatonin signaling during hibernation at an elevated temperature to test the hypothesis that decreased melatonin is sufficient to activate the reproductive axis in response to low-temperature dormancy. We used the melatonin receptor antagonist luzindole to inhibit melatonin signaling; luzindole is a well-characterized and widely used nonselective antagonist for the melatonin type $1 \mathrm{a}$ and $1 \mathrm{~b}$ receptors found in all vertebrates [Dubocovich, 1988; Dubocovich et al., 1990; Dubocovich et al., 2003; Boutin et al., 2005]. Animals hibernated at $12^{\circ} \mathrm{C}$ were treated with $2.0 \mathrm{mg}$ of luzindole (N-Acetyl-2-benzyl-tryptamine, product number Q1885, Bachem Americas, Inc.) diluted in $50 \mu \mathrm{L}$ of $10 \%$ dimethyl sulfoxide (DMSO) in $80 \%$ ethanol. The dose approximated by these injections was $50 \mu \mathrm{g} / \mathrm{g}$ body mass (males average $40 \mathrm{~g}$ ) and is similar to doses used previously in both mammals and ectotherms [Dubocovich et al., 1990; Pinillos et al., 2001]. Control treatments consisted of the vehicle only (i.e., $50 \mu \mathrm{L}$ of $10 \%$ DMSO in $80 \%$ ethanol). Treatments were administered via intraperitoneal injection every 3 days for the entire hibernation period.

Despite several pilot studies conducted in our lab to validate the luzindole treatments and its effects on male courtship behavior, snakes in this experiment had an unexpected and negative response to prolonged, repeated injections of luzindole during dormancy. We observed increased mortality after approximately 5 weeks of luzindole treatments. The mortality rate typically observed during hibernation of garter snakes for 16-24 weeks in our lab is less than $1 \%$. Prior to week 5 , the mortality rate of all snakes was also $<1 \%$. During week 5 , however, the mortality rate in the luzindole treatment group increased to $30 \%$, while the mortality 


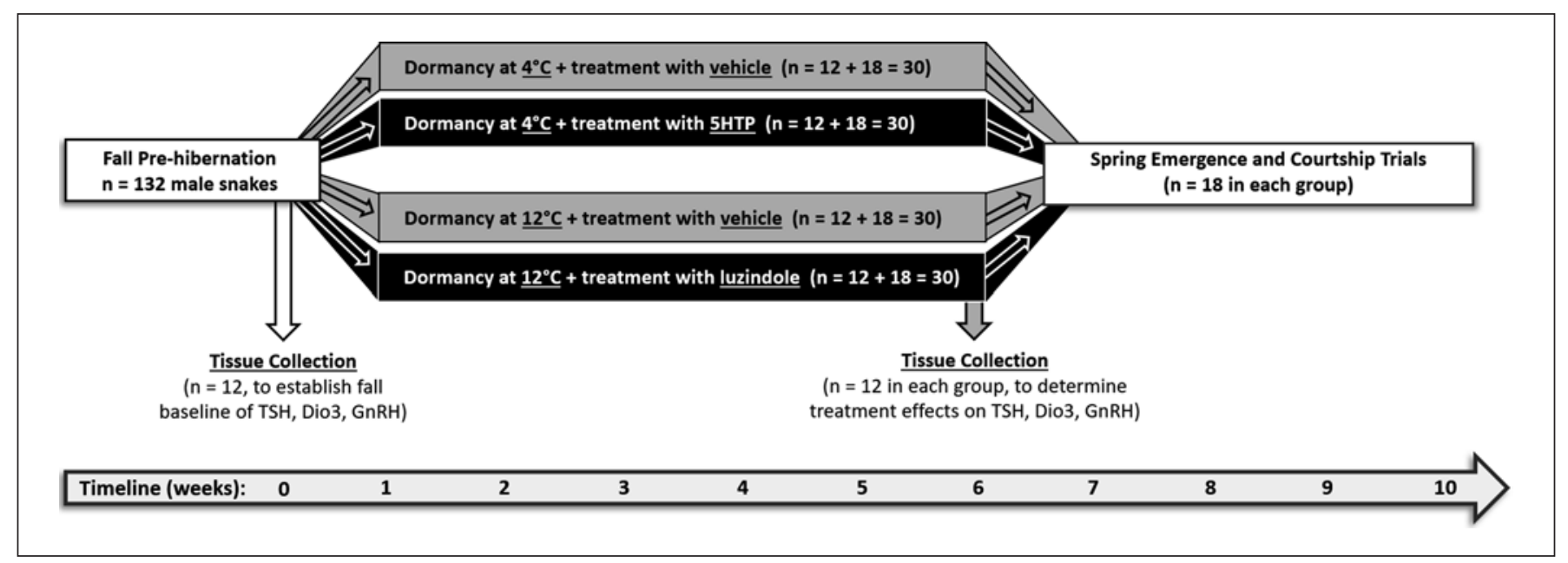

Fig. 2. Experimental design for testing if melatonin is necessary and sufficient for meditating the effects of low-temperature dormancy on the neuroendocrine reproductive axis of red-sided garter snakes (Thamnophis sirtalis parietalis). Animals were collected from the field and assigned to one of five groups: a pre-hibernation group to establish a fall baseline of immunoreactivity, hibernation at $4^{\circ} \mathrm{C}$ for 6 weeks and treatment with vehicle or the melatonin precursor 5-hydroxytryptophan $(5 \mathrm{HTP})$, or hibernation at $12^{\circ} \mathrm{C}$

rate in the respective control group was 3.3\%. Luzindole is not known to be cytotoxic in organismal studies, and, therefore, the cause of this increased mortality remains unknown. Although we had planned to retain snakes in hibernation for 8 weeks prior to measuring the effects of these treatments on neuropeptides and courtship behavior, once we observed the increased mortality rate during week 5, we immediately ceased all treatments and ended the experiment after 6 weeks of hibernation. Importantly, our revised sampling time is still within the critical window of 3-8 weeks of low-temperature exposure when significant changes in behavior and hormones are observed [e.g., Garstka et al., 1982]. We redistributed the remaining luzindole-treated animals to optimize sample sizes for brain immunohistochemistry versus behavior. Final sample sizes for all treatment groups are shown in the Figures.

\section{Tissue Processing and Collection}

Snakes were euthanized via injection with $250 \mu \mathrm{L}$ of $1 \%$ Brevital sodium near the heart and decapitated. Brains were fixed by immersion in $4 \%$ paraformaldehyde in $0.1 \mathrm{M}$ phosphate buffer $(\mathrm{pH}$ 7.2) for $16 \mathrm{~h}$ at $4^{\circ} \mathrm{C}$ and then rinsed and stored in $0.1 \mathrm{M}$ phosphate buffer ( $\mathrm{pH}$ 7.2). Brains were dissected with the ventral skull left intact and then decalcified by incubating tissues in $10 \%$ ethylenediaminetetraacetic acid (EDTA) diluted in $0.1 \mathrm{M}$ phosphate buffer ( $\mathrm{pH}$ 7.2) solution for 3 days; tissues were transferred to fresh solution each day. The brain and decalcified ventral skull were then cryoprotected in $30 \%$ sucrose in $0.1 \mathrm{M}$ phosphate buffer. Brains with ventral skull still intact were sectioned on a cryostat (Leica 3050S) into four series of 25- $\mu \mathrm{m}$ sagittal sections that were thawmounted onto subbed slides (Superfrost Plus, ThermoFisher Scientific, Inc., Pittsburgh, PA, USA). Slides were stored at $-20^{\circ} \mathrm{C}$ prior to immunohistochemical staining.

Melatonin and Temperature-Induced Changes in the Reproductive Axis for 6 weeks and treatment with vehicle or the melatonin receptor antagonist luzindole. Within each hibernation treatment group, snakes were further divided into two subgroups to determine the influence of treatment on immunoreactive cell number in the brain $(n=12)$ or courtship behavior $(n=18)$. Spring emergence was simulated with spring-like environmental conditions $(16: 8 \mathrm{~h}$ L:D photoperiod and $25: 20^{\circ} \mathrm{C}$ thermoperiod). Courtship behavior was assessed during weeks 6-10 of the experiment.

\section{Immunohistochemistry - Primary Antibodies and Control}

Tests

We examined the effects of melatonin treatment on TSH within the infundibulum of the pituitary gland as well as thyroid hormone metabolism and GnRH in the hypothalamus using immunohistochemistry. To assess changes in hypothalamic thyroid hormone metabolism, we performed immunohistochemistry for the Dio3 peptide; Dio3 enzymatically inactivates $\mathrm{T}_{3}$ by converting it to reverse $\mathrm{T}_{3}$ and/or diiodothyronine $\left(\mathrm{T}_{2}\right)$. The expression of Dio3 mRNA is significantly decreased in the hypothalamus during photoperiod-induced activation of the reproductive axis [e.g., Yasuo et al., 2005], which in turn favors the accumulation of bioactive $\mathrm{T}_{3}$. For logistical reasons, we were not able to assess possible changes in the Dio2 peptide in this experiment; Dio2 enzymatically converts $\mathrm{T}_{4}$ into $\mathrm{T}_{3}$.

TSH immunoreactivity was examined using a polyclonal antigarter snake TSH antiserum generated in rabbit (PAC 12291-92). Similarly, Dio3 immunoreactivity was examined using a rabbit polyclonal, anti-garter snake Dio3 antiserum (PAC 59160). These antibodies were custom generated by Pacific Immunology, Inc., against the amino acid sequences for the $\beta$ subunit of TSH (TSH $\beta$ ) and Dio3 predicted from the cDNA sequences we previously isolated from garter snake tissues (brain and pituitary). Primers used for PCR amplification and resulting cDNA sequences are shown in Table 2. GnRH immunoreactivity was examined using a commercially available, polyclonal rabbit anti-GnRH1 antiserum (PA1-122 ThermoFisher Scientific, Inc.).

To validate the specificity of each primary antibody in our assays, we first performed a series of immunohistochemistry controls using omission of the primary antibodies and pre-adsorption tests. Prior to immunohistochemistry, rabbit anti-TSH and rabbit 
Table 2. Primers used for PCR and the resulting cDNA sequences isolated from the combined brain and pituitary tissues of red-sided garter snakes (Thamnophis sirtalis parietalis)

\begin{tabular}{|c|c|c|c|c|}
\hline Gene & \multicolumn{2}{|c|}{$\begin{array}{l}\text { Forward and reverse primers, } 5^{\prime} \text { to } 3^{\prime} \text { (degenerate primers } \\
\text { contain mixed bases) }\end{array}$} & $\begin{array}{l}\text { Base pairs in } \\
\text { isolated cDNA }\end{array}$ & \% sequence identity (accession No.) \\
\hline TSH $\beta$ & $\begin{array}{l}\mathrm{F}: \\
\mathrm{R}:\end{array}$ & $\begin{array}{l}\text { AAGACTGTGCAGCCAAGAGACTGA } \\
\text { ACATITGCAACTCACTGCCACAGG }\end{array}$ & 402 & $\begin{array}{l}\text { 96\% with brown tree snake } \\
\text { (AB575987.1) }\end{array}$ \\
\hline Dio3 & $\begin{array}{l}\text { F: } \\
\text { R: }\end{array}$ & $\begin{array}{l}\text { GGSCAGAARYTGGAYTTYTTCAAG } \\
\text { TGACCCAGCCGTCGGADGGGTG }\end{array}$ & 267 & 86\% with chicken (Y11273.1) \\
\hline
\end{tabular}

The above CDNA sequences were used to predict amino acid sequences for the $\beta$ subunit of thyroid-stimulating hormone (TSH $\beta$ ), deiodinase 3 (Dio3), and gonadotropin-releasing hormone ( $\mathrm{GnRH})$ peptides. These were in turn used to generate custom antibodies targeting garter snake peptides (TSH and Dio3) or corroborate results of immunoreactive staining with commercially available antiserum $(\mathrm{GnRH})$. Because the mature $\mathrm{GnRH}$ peptide contains only 10 amino acids, forward and reverse primers were generated using the conserved synteny relationship between the genes encoding GnRH1 and potassium channel tetramerization domain containing 9 (KCTD9) as in Ikemoto and Park [2007]. The resulting amplified cDNA sequence in garter snake brain was 1,221 base pairs, which contains a 27-base pair sequence (CAGCACTGGTCCTACGGGTTACAAGGG) for which the \% sequence identity is reported above.

anti-Dio3 antisera were diluted 1:1,000 in buffer (see next section) and incubated overnight at $4^{\circ} \mathrm{C}$ with $1 \mathrm{mg}$ of TSH $\beta$ or Dio3 peptide per $\mathrm{mL}$ of antibody solution, respectively. The peptides used for these pre-adsorption tests were synthesized by Pacific Immunology, Inc., and used as the inoculating antigens for antibody production. Pre-adsorption tests for the GnRH1 antiserum are described in Lutterschmidt et al. [2022] and the results corroborated by the cDNA sequence for $\mathrm{GnRH}$ isolated from red-sided garter snakes (Table 2). All tissues used in antibody omission and preadsorption tests were independent from the animals used in the hibernation experiments, and all tissues were processed in the same assay.

\section{Immunohistochemistry Assays}

For each peptide, one series of tissues was processed in a single assay using the methods detailed in Lutterschmidt and Maine [2014]. Slides that contained the hypothalamic region and the pituitary were defrosted and dried on a slide warmer at $50^{\circ} \mathrm{C}$ for 45 min and outlined with a hydrophobic barrier (Liquid Blocker Super Pap Pen; Electron Microscopy Sciences, Hatfield, PA, USA). Slides were then incubated for $5 \mathrm{~min}$ in $4 \%$ paraformaldehyde in $0.1 \mathrm{M}$ phosphate-buffered saline (PBS; $\mathrm{pH} 7.4$ ). We washed the slide-mounted tissues 3 times for 5 min each with $0.1 \mathrm{M}$ PBS; this was completed after every step of the assay to reduce potential background staining. The paraformaldehyde fixative was neutralized with a $0.1 \%$ sodium borohydride solution ( $\mathrm{pH} 8.5$ ) for $20 \mathrm{~min}$ and endogenous peroxidase activity quenched with $3 \%$ hydrogen peroxide $\left(\mathrm{H}_{2} \mathrm{O}_{2}\right)$ in methanol for $30 \mathrm{~min}$. Slides were washed 2 times for 5 min each with $0.1 \mathrm{M}$ PBS followed by 1 time for $5 \mathrm{~min}$ in $0.3 \%$ Triton X solution in $0.1 \mathrm{M}$ PBS (PBS-T). We incubated the slides for 60 min with a blocking solution of $10 \%$ horse serum (item H1270, Sigma-Aldrich Co.) and 10\% avidin (item SP-2001, Vector Labs, Burlingame, CA, USA) to reduce nonspecific binding. Tissues were then incubated with primary antibody at a dilution of 1:1,000 in $10 \%$ horse serum and 10\% biotin (item SP-2001, Vector
Labs) in PBS-T. Sections were coverslipped with parafilm and allowed to incubate with the primary antibody for $48 \mathrm{~h}$ at $4^{\circ} \mathrm{C}$ in a humid chamber.

The primary antibody signal was amplified via incubation with biotinylated horse anti-rabbit secondary antibody (item BA-1100, Vector Labs) diluted 1:400 in PBS-T for $60 \mathrm{~min}$. Tissues were then incubated with avidin conjugated to horseradish peroxidase (Elite ABC peroxidase kit, item PK-6100, Vector Labs). Primary antibody binding was visualized with a chromogenic reaction carried out with a $0.25 \mathrm{mg} / \mathrm{mL}$ solution of diaminobenzidine (item $0430-5 \mathrm{G}$; BioExpress, Kaysville, UT, USA) diluted in $0.2 \% \mathrm{H}_{2} \mathrm{O}_{2}$ in $0.05 \mathrm{M}$ Tris-HCL buffer ( $\mathrm{pH}$ 7.2). The reaction was terminated by immersing the slides in 3 washes of nanopure $\mathrm{H}_{2} \mathrm{O}$ for 5 min each. Tissues were dehydrated using a series of graded ethanol washes $(70,85,95$, 100 , and 100\%) for 2 min each, cleared with Citrasolv (Fisher Scientific), and then sealed with Permount and glass coverslips.

\section{Immunoreactive Cell Counting}

Immunoreactive cell counting of stained tissues was performed using an Olympus BX40 microscope with a QIClick digital camera and QImaging software (QImaging; Surrey, BC, Canada). As in many neurobiology studies, we interpreted an increase in the number of immunoreactive cells as an indication that a greater number of cells within a given cell population were producing sufficient amounts of peptide to reach the threshold of detection for immunohistochemistry. While an increase in the number of immunoreactive cells suggests that more cells within the cell population are actively synthesizing and/or accumulating the target peptide, labeling with diaminobenzidine cannot be used to directly assess the concentration of peptide either across the cell population or within individual cells.

The locations of immunoreactive cells were mapped onto sagittal sections using anatomical brain sections adapted from Krohmer et al. [2010] and Maine et al [2014]. Animals were coded so that the observer was blind to the treatment group of individuals. For 
Table 3. Ethogram of courtship behavior for male red-sided garter snakes (Thamnophis sirtalis parietalis)

\begin{tabular}{ll}
\hline $\begin{array}{l}\text { Courtship } \\
\text { score }\end{array}$ & Description of behavior \\
\hline 0 & No reproductive behavior \\
\hline 1 & Male investigates female, increased tongue-flick rate \\
\hline 2 & Male chin-rubs female with rapid tongue-flicks \\
\hline 3 & Male aligns body with female \\
\hline 5 & $\begin{array}{l}\text { Male actively tail searches and attempts cloacal } \\
\text { caudocephalic waves }\end{array}$ \\
\hline
\end{tabular}

Behaviors equal to and above 2 are exhibited only in a reproductive context. This ethogram using whole numbers was taken from Lutterschmidt et al. [2004]; for logistical reasons in recording scores of many snakes in multiple mating trials, it was modified from the half-point scale ranging from $0-3$ used in Crews et al. [1984]. An additional modification was made by combining the behaviors of caudocephalic waves and tail wrestling with possible cloacal apposition into one score, because these behaviors typically occur in rapid succession or simultaneously.

each peptide of interest, immunoreactive cells were counted and quantified manually in all sections containing the hypothalamus and pituitary region under $\times 200$ magnification and again at $\times 400$ magnification. If the counts were not identical, the section was recounted under $\times 400$ magnification to verify cell counts. We followed counting methods and criteria described by Lutterschmidt and Wilczynski [2012]. The number of immunoreactive cells was quantified in one tissue series and then totaled for each individual. Missing and/or severely damaged sections were assigned the mean cell count of the previous and subsequent tissue section. If two or more consecutive sections were unusable, the animal was excluded from statistical analysis. Because each brain was divided into 4 different series of $25-\mu \mathrm{m}$ sections, approximately $100 \mu \mathrm{m}$ separated each section within a series, thereby eliminating the possibility that labeled cells were double counted and our cell counts were inflated.

\section{Courtship Behavior}

Following 6 weeks of hibernation in combination with hormone manipulations, animals were subjected to simulated spring emergence and housed under spring-like environmental conditions (Table 1). Using an ethogram of male courtship behavior (Table 3), we measured the courtship behavior of each male on days $1,3,7,10,14$, and 21 after emergence. During each courtship trial, we scored the behavior of each male 10, 30, and $60 \mathrm{~min}$ following the introduction of a sexually attractive stimulus female into each arena. Males were tested in groups of 8 to simulate natural mating conditions, where mating balls rarely contain fewer than 5 males courting a single female [Joy and Crews, 1985]. Males from each treatment group were equally distributed across all behavior arenas. Because female red-sided garter snakes become un- attractive and unreceptive after mating, we covered each female's cloaca with medical adhesive tape to prevent mating during the courtship trial [e.g., Lutterschmidt et al., 2004]. Thus, the highest courtship score each male could achieve was 4.0. We used these data to calculate a mean and maximum courtship score for each male on each day after emergence. At the conclusion of the behavior experiments, animals were maintained in the lab until they were returned to their site of capture and released.

\section{Statistics}

We used SigmaPlot 12.5 (Systat Software 2010, Systat Systems, Inc., Port Richmond, CA, USA) to perform all statistical analyses. Statistical comparisons were considered significant at $p \leq 0.05$. Except where noted, all data met the assumptions of normality and equal variance required for parametric tests. We first used a oneway ANOVA within each temperature group to confirm that neither body mass nor snout-vent length varied significantly between treatment groups. For each peptide, we used a $t$ test to compare the number of immunoreactive cells during the fall pre-hibernation period (i.e., baseline) to (1) the number of labeled cells following 6 weeks of dormancy with vehicle treatment and (2) the number of labeled cells following 6 weeks of dormancy with 5HTP or luzindole treatment. This allowed us to determine if there was a significant change in the immunoreactive cell number of animals after 6 weeks of dormancy with and without hormone manipulation.

To assess the effects of hibernation temperature and hormone treatments on behavior, we used a two-way repeated-measures analysis of variance (ANOVA) followed by a Holm-Sidak multiple-comparisons test to detect possible differences in both average and maximum courtship scores between treatment groups. The within-subjects factor was days post-emergence and each day was compared against the first day (day 1) of emergence in the multiple-comparisons test. Separate analyses were performed for each hibernation temperature, and all pairwise comparisons were not performed to maintain statistical power.

\section{Results}

Omission of each primary antibody from the immunohistochemistry assay eliminated immunoreactive staining. Control tests with each primary antiserum pre-adsorbed with the respective peptide also eliminated all immunoreactive staining (Fig. 3; see also [Lutterschmidt et al., 2022]).

In addition to positive TSH $\beta$ staining in the anterior pituitary gland, we observed a distinct population of TSH-immunoreactive (ir) cells located within the median eminence and infundibulum of the pituitary gland of all snakes (Fig. 3); we refer to this cell population collectively as the infundibulum from this point onward. Although few in number, a small cluster of TSH-ir cells was also consistently observed in the caudal aspect of the ventral hypothalamus, located adjacent to the most ventral regions of the third ventricle within the mediobasal hypothalamus. There is precedence for TSH $\beta$ being localized outside of the pituitary [Joseph and Knigge, 1974]. More- 


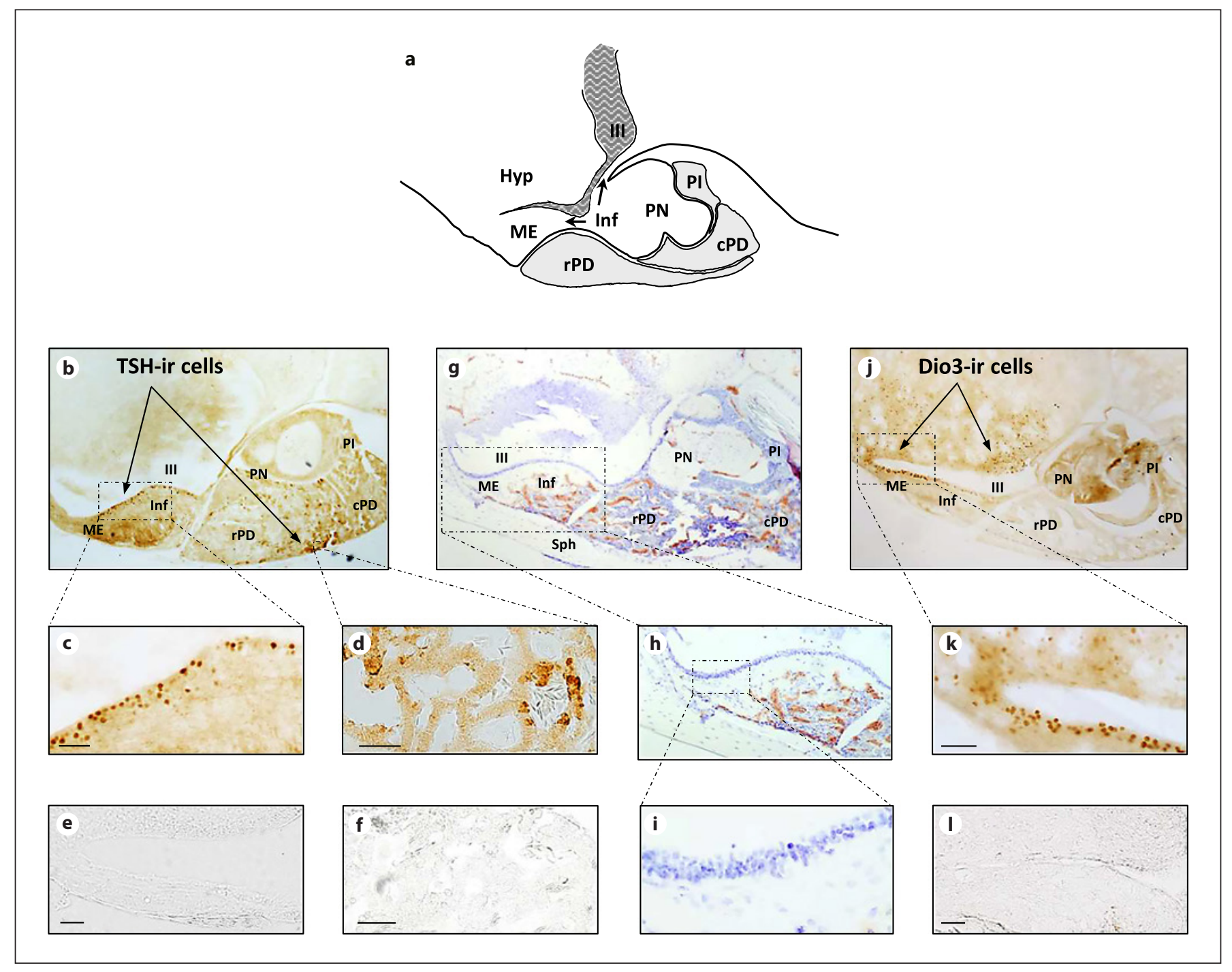

Fig. 3. Localization of thyroid-stimulating hormone (TSH) and deiodinase 3 (Dio3) immunoreactivity in the brain of male red-sided garter snakes (Thamnophis sirtalis parietalis). a Representative schematic showing the anatomical relationship between the hypothalamus and pituitary gland in garter snakes in the sagittal plane (adapted from Schreibman [1986]). The third ventricle is shaded in dark gray with hashed lines; both zones of the pars distalis and the pars intermedia are shaded in light gray. b Example photomicrograph showing the distribution of TSH-labeled cells in the median eminence, infundibulum, and anterior pituitary gland. Boxes delineate magnified spaces in the infundibulum (c) and anterior pituitary (d). e, f Example photomicrographs of TSH immunohisto-

over, positive immunoreactivity does not require that the peptide target has been synthesized within that cell [e.g., Schreibman, 1986]. Given the proximity of TSH $\beta$-ir cells to the third ventricle within the mediobasal hypothalamus, it is possible that these are the retrograde cells that chemistry in the infundibulum and anterior pituitary, respectively, following control tests with pre-adsorbed antiserum. g-i Images of the median eminence, infundibulum, and pituitary gland counterstained with cresyl violet acetate. $\mathbf{j}$ Example photomicrograph showing the distribution of Dio3-labeled cells in the median eminence, infundibulum, and ventral hypothalamus; box delineates magnified space in $\mathbf{k}$. I Example photomicrograph of Dio3 immunohistochemistry following pre-adsorption tests. The rostral brain is oriented to the left in all sections; all scale bars are $50 \mu \mathrm{m}$. cPD, caudal pars distalis; Hyp, hypothalamus; Inf, infundibulum; ME, median eminence; PI, pars intermedia; PN, pars nervosa; $\mathrm{rPD}$, rostral pars distalis; Sph, sphenoid bone; III, third ventricle. 
Table 4. Summary of results examining the influence of melatonin signaling on the number of cells immunoreactive (ir) for thyroid-stimulating hormone (TSH), deiodinase 3 (Dio3), or gonadotropin-releasing hormone (GnRH) in redsided garter snakes (Thamnophis sirtalis parietalis)

\begin{tabular}{|c|c|c|c|c|c|c|}
\hline \multirow[t]{2}{*}{ Treatment group } & \multicolumn{2}{|l|}{ TSH-ir cells } & \multicolumn{2}{|l|}{ Dio3-ir cells } & \multicolumn{2}{|l|}{ GnRH-ir cells } \\
\hline & Mean ( \pm SEM) & $p$ value & Mean ( \pm SEM) & $p$ value & Mean ( \pm SEM) & $p$ value \\
\hline Pre-hibernation & $134.7 \pm 16.50$ & - & $864.1 \pm 61.15$ & - & $50.6 \pm 11.81$ & - \\
\hline $4^{\circ} \mathrm{C}+$ vehicle & $83.7 \pm 19.73$ & 0.050 & $794.1 \pm 95.59$ & 0.268 & $45.4 \pm 11.17$ & 0.378 \\
\hline $4^{\circ} \mathrm{C}+5-\mathrm{HTP}$ & $132.3 \pm 19.31$ & 0.941 & $1,020.1 \pm 92.83$ & 0.084 & $72.7 \pm 20.20$ & 0.168 \\
\hline $12^{\circ} \mathrm{C}+$ vehicle & $162.1 \pm 25.74$ & 0.196 & $828.8 \pm 103.22$ & 0.382 & $50.0 \pm 10.43$ & 0.486 \\
\hline $12^{\circ} \mathrm{C}+$ luzindole & $162.1 \pm 25.75$ & 0.201 & $838.1 \pm 59.81$ & 0.388 & $108.7 \pm 33.57$ & 0.040 \\
\hline
\end{tabular}

A pre-hibernation group was used to establish a fall baseline level of immunoreactive cells prior to manipulating temperature and melatonin. We predicted that 6 weeks of dormancy at $4^{\circ} \mathrm{C}$ would increase TSH-ir, decrease Dio3ir, and increase $\mathrm{GnRH}$-ir, and that treatment with the melatonin precursor 5-hydroxytryptophan (5-HTP) to elevate melatonin concentrations would reverse these effects. Similarly, we predicted that 6 weeks of dormancy at an elevated temperature of $12^{\circ} \mathrm{C}$ would result in no changes in immunoreactive staining, but simultaneous inhibition of melatonin signaling via treatment with the melatonin receptor antagonist luzindole would increase TSH-ir, decrease Dio3-ir, and increase GnRH-ir. All $p$ values are from $t$ tests comparing each treatment to the pre-hibernation baseline.

cused our analysis of TSH immunoreactivity in this experiment on cells localized within the infundibulum of the pituitary gland.

Immunoreactive Dio3 cells were observed within the median eminence, infundibulum of the pituitary gland, and ventral hypothalamus, from the rostral aspect of the median eminence through the caudal mediobasal hypothalamus (Fig. 3). Based on the hypothesis that changes in thyroid hormone metabolism specifically within the hypothalamus mediate the effects of temperature on the reproductive axis, we excluded cells in the infundibulum from our Dio3 cell counts, instead choosing to focus our analyses on changes in hypothalamic Dio3 immunoreactivity. Moreover, our preliminary analyses comparing changes in Dio3-ir cells between the hypothalamus and infundibulum indicated that seasonal changes in Dio3 were driven by changes specifically within the hypothalamus, with no significant changes observed within the infundibulum (not shown).

Finally, similar to Smith et al. [1997] and as reported in Lutterschmidt et al. [2022], we observed GnRH-ir cell bodies and/or fibers in the olfactory bulb, dorsal pallium of the rostral telencephalon, medial forebrain bundle, terminal nerve, lateral and medial septum, diagonal band of Broca, amygdala, medial and lateral preoptic area, suprachiasmatic nuclei, hypothalamus in the caudal forebrain, and median eminence. We quantified GnRH-ir cell bodies in the terminal nerve ganglion, nucleus of the diagonal band of Broca, septum, and medial preoptic area.

Melatonin and Temperature-Induced Changes in the Reproductive Axis
Influence of Melatonin Signaling on Neuropeptide Immunoreactivity

Our immunohistochemistry results are summarized in Table 4. In contrast to our prediction, we observed a significant decrease in the number of TSH-labeled cells in the infundibulum of male snakes after 6 weeks of lowtemperature dormancy at $4^{\circ} \mathrm{C}(t=2.091, \mathrm{df}=18, p=$ 0.050; Fig. 4a). Treatment of snakes with the melatonin precursor 5-hydroxytryptophan eliminated the decrease in TSH-ir cells in response to 6 weeks of hibernation at $4^{\circ} \mathrm{C}(t=0.0746, \mathrm{df}=21, p=0.941$; Fig. 4a $)$. Neither Dio3ir $(t=0.628, \mathrm{df}=21, p=0.269$; Fig. $4 \mathrm{~b})$ nor GnRH-ir $(t=$ $0.316, \mathrm{df}=15, p=0.378$; Fig. $4 \mathrm{c})$ cell number was altered by 6 weeks of low-temperature dormancy at $4^{\circ} \mathrm{C}$. Treatment of snakes with 5-hydroxytryptophan during lowtemperature dormancy did not significantly alter the number of cells labeled for Dio3 $(t=-1.426, \mathrm{df}=21, p=$ 0.084; Fig. $4 \mathrm{~b})$ or $\mathrm{GnRH}(t=-0.998, \mathrm{df}=14, p=0.168$; Fig. 4c) within the hypothalamus.

There was no significant change in the number of TSH-labeled cells in the infundibulum of male snakes after 6 weeks of dormancy at an elevated temperature of $12^{\circ} \mathrm{C}(t=-0.875, \mathrm{df}=19, p=0.196$; Fig. 5a). Likewise, neither Dio3-ir ( $t=0.306, \mathrm{df}=20, p=0.382$; Fig. $5 \mathrm{~b})$ nor GnRH-ir $(t=0.035, \mathrm{df}=16, p=0.486$; Fig. $5 \mathrm{c})$ cell number in the hypothalamus was altered in response to 6 weeks of dormancy at $12^{\circ} \mathrm{C}$. Treatment of snakes with the melatonin receptor antagonist luzindole did not alter the observed responses of TSH $(t=-0.860, \mathrm{df}=16, p=0.201$; 
Fig. 4. Effect of low-temperature winter dormancy on the number of cells immunoreactive (ir) for thyroid-stimulating hormone (TSH) (a) in the median eminence and infundibulum, deiodinase 3 (Dio3) (b) in the ventral hypothalamus, and gonadotropin-releasing hormone $(\mathrm{GnRH})$ (c) in the preoptic area of male red-sided garter snakes (Thamnophis sirtalis parietalis). Samples collected at time 0 occurred prior to snakes being subjected to any temperature or hormone manipulation and serve as a fall, pre-hibernation baseline. Snakes were hibernated at an ecologically relevant temperature of $4^{\circ} \mathrm{C}$ for 6 weeks in complete darkness; snakes received intraperitoneal injections of vehicle or 5-hydroxytrptophan (5-HTP) every 3 days throughout the dormancy period. 5-HTP is a precursor for melatonin synthesis and is known to increase plasma melatonin concentrations in garter snakes [Lutterschmidt and Mason, 2010]. Data are the means + 1 SE; sample sizes are listed along the $x$-axes.

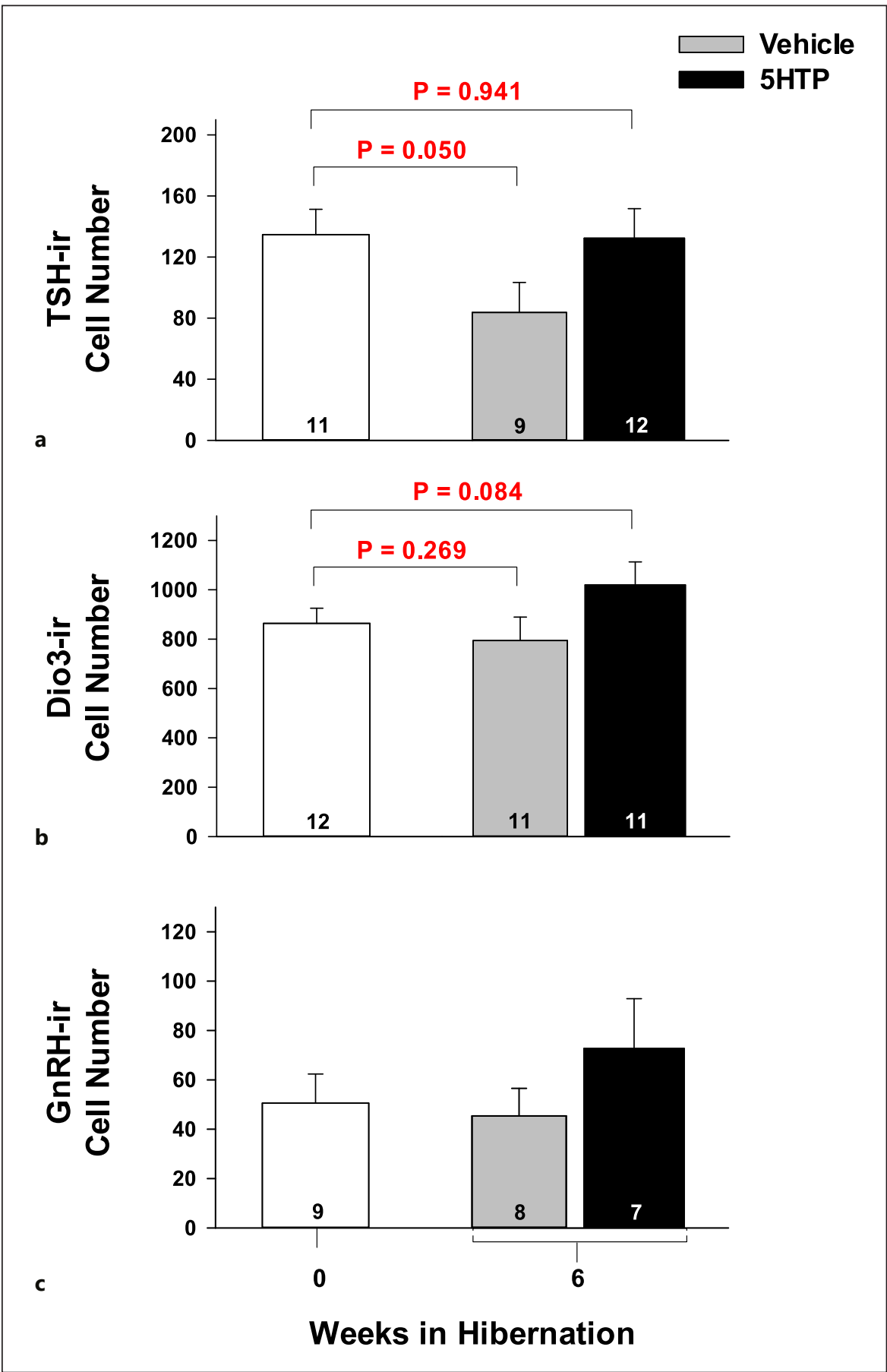

Fig. 5a) or Dio3 $(t=0.290, \mathrm{df}=18, p=0.388$; Fig. 5b) immunoreactivity to dormancy at $12^{\circ} \mathrm{C}$. However, the number of GnRH-ir cells was significantly increased in the brain of luzindole-treated males $(t=-1.898, \mathrm{df}=13, p=$ 0.040; Fig. 5c).

\section{Influence of Melatonin Signaling on Courtship}

\section{Behavior}

For males hibernated at $4^{\circ} \mathrm{C}$ for 6 weeks, the main effects of 5-hydroxytryptophan versus vehicle treatment on mean courtship score were statistically nonsignificant $\left(F_{1,198}=2.019, p=0.165\right.$, from a two-way repeated mea-
Winters/Martin/Anderson/Procter/ Lutterschmidt 
Fig. 5. Effect of elevated hibernation temperature $\left(12^{\circ} \mathrm{C}\right)$ on the number of cells immunoreactive (ir) for thyroid-stimulating hormone (TSH) (a) in the median eminence and infundibulum, deiodinase 3 (Dio3) (b) in the ventral hypothalamus, and gonadotropin-releasing hormone $(\mathrm{GnRH})$ (c) in the preoptic area of male red-sided garter snakes (Thamnophis sirtalis parietalis). Samples collected at time 0 occurred prior to snakes being subjected to any temperature or hormone manipulation and serve as a fall, pre-hibernation baseline. Snakes were hibernated at an elevated temperature of $12^{\circ} \mathrm{C}$ for 6 weeks in complete darkness; snakes received intraperitoneal injections of vehicle or luzindole, a melatonin receptor type $1 \mathrm{a}$ and $\mathrm{lb}$ antagonist, every 3 days throughout the dormancy period. Data are the means +1 SE; sample sizes are listed along the $x$-axes.

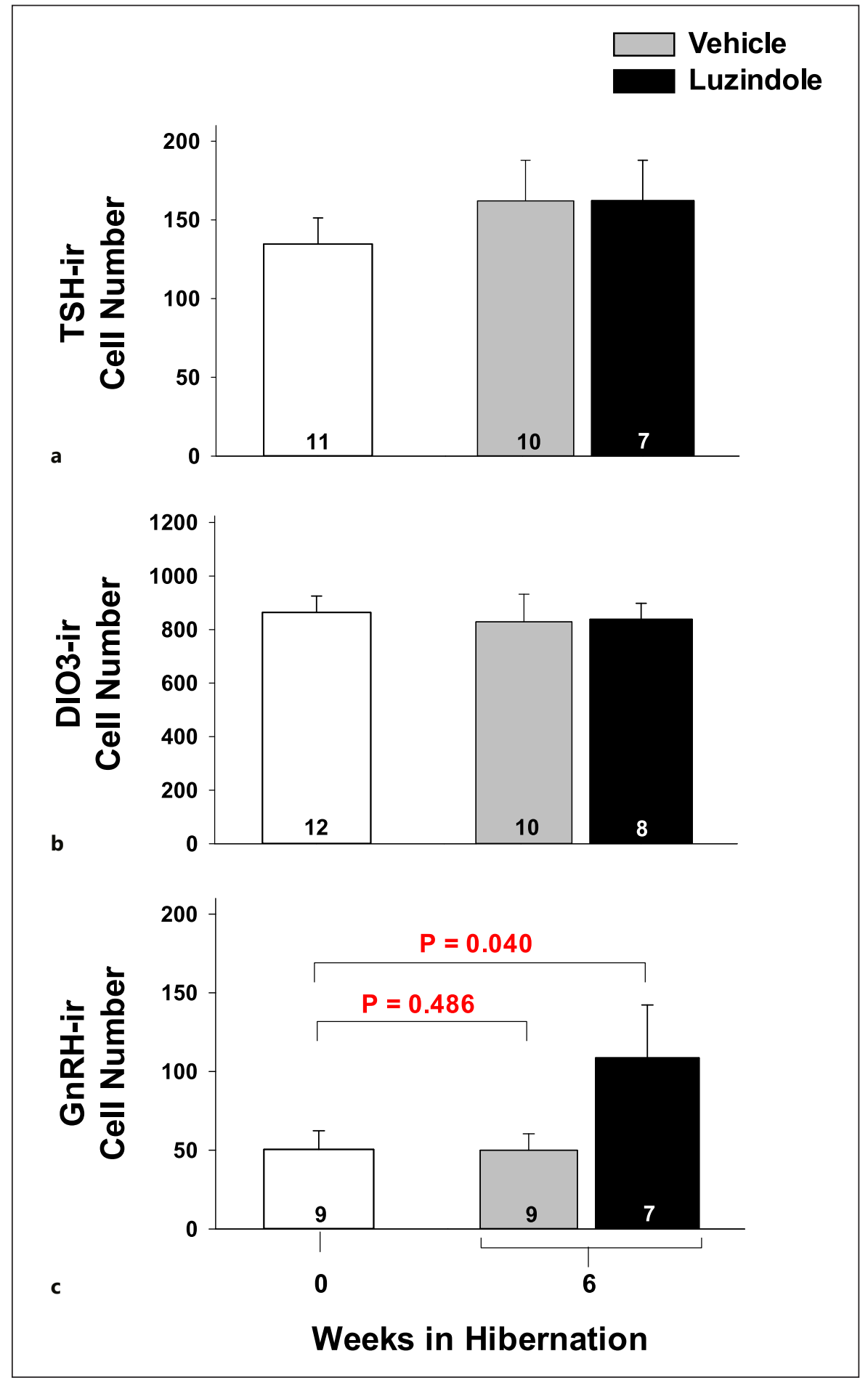

sures ANOVA; Fig. 6a). However, mean courtship score varied significantly with days post-emergence $\left(F_{6,198}=\right.$ $9.010, p<0.001$; Fig. 6a). The interaction between treatment and days post-emergence was statistically nonsignificant $\left(F_{6,198}=1.605, p=0.147\right)$.

Melatonin and Temperature-Induced Changes in the Reproductive Axis
To assess the effects of 5-hydroxytryptophan treatment on courtship intensity, we investigated possible differences in the maximum courtship score achieved by males between treatments and across days post-emergence. While the main effects of treatment on maximum 


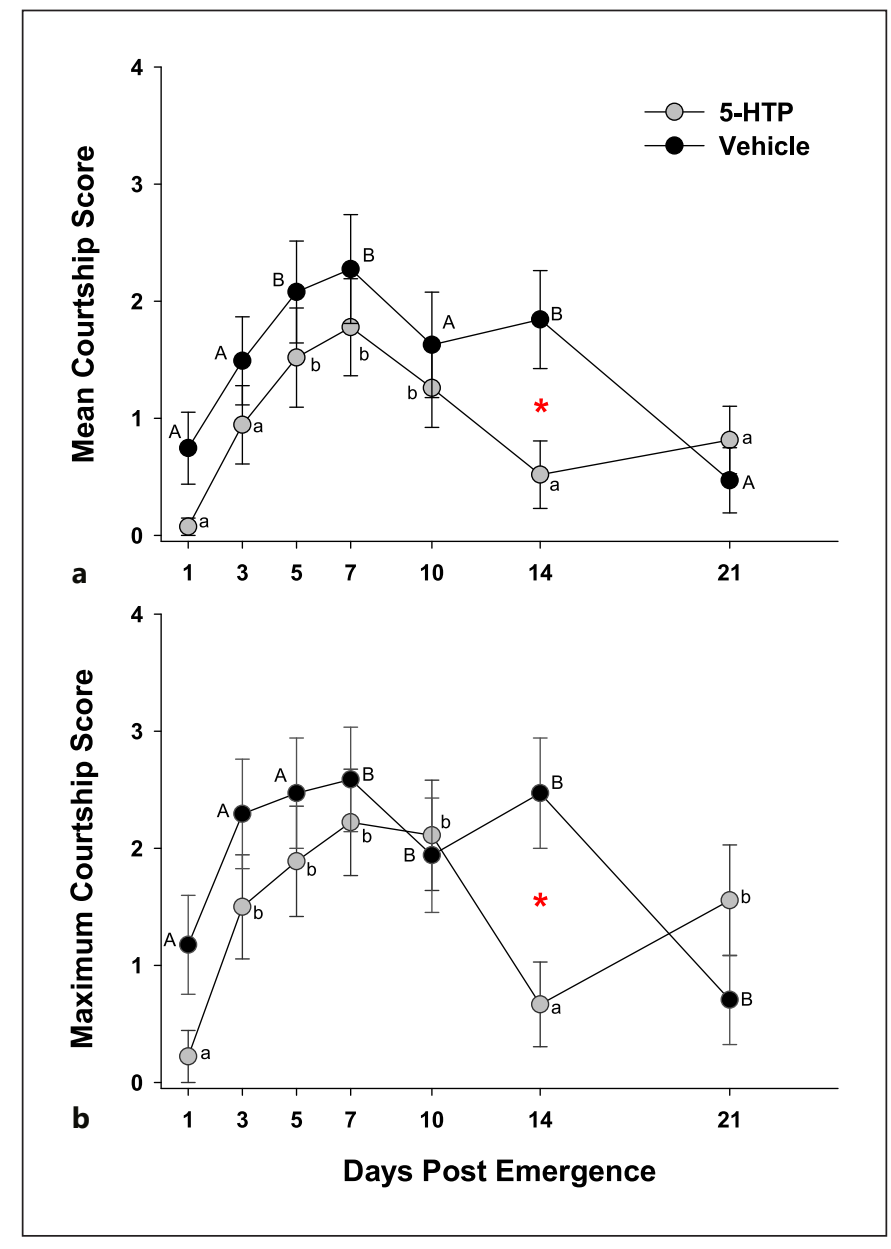

Fig. 6. Influence of vehicle ( $n=17)$ and 5-hydroxytryptophan (5HTP, $n=18$ ) treatment on the mean (a) and maximum (b) courtship scores achieved by male red-sided garter snakes (Thamnophis sirtalis parietalis) following emergence from simulated winter dormancy at $4^{\circ} \mathrm{C}$ for 6 weeks. Treatment of snakes with the melatonin precursor 5-HTP is known to increase plasma melatonin concentrations in this species. Capital letters indicate significant differences between days post-emergence within the vehicle treatment group; lower-case letters indicate significant differences between days within the 5-HTP group. For both analyses, multiple-comparisons tests were performed by comparing each day post-emergence to day 1 (i.e., all pairwise comparisons were not performed to maintain statistical power). Data are the means \pm 1 SE.

courtship score were statistically nonsignificant $\left(F_{1,198}=\right.$ $1.456, p=0.236$ ), we observed a significant change in maximum courtship score over days post-emergence $\left(F_{6,198}=5.989, p<0.001 ;\right.$ Fig. 6 b $)$. In addition, the interaction between treatment and days post-emergence was statistically significant $\left(F_{6,198}=2.898, p=0.010\right)$, indicating that the change in courtship intensity over time depended on treatment condition (Fig. 6b).

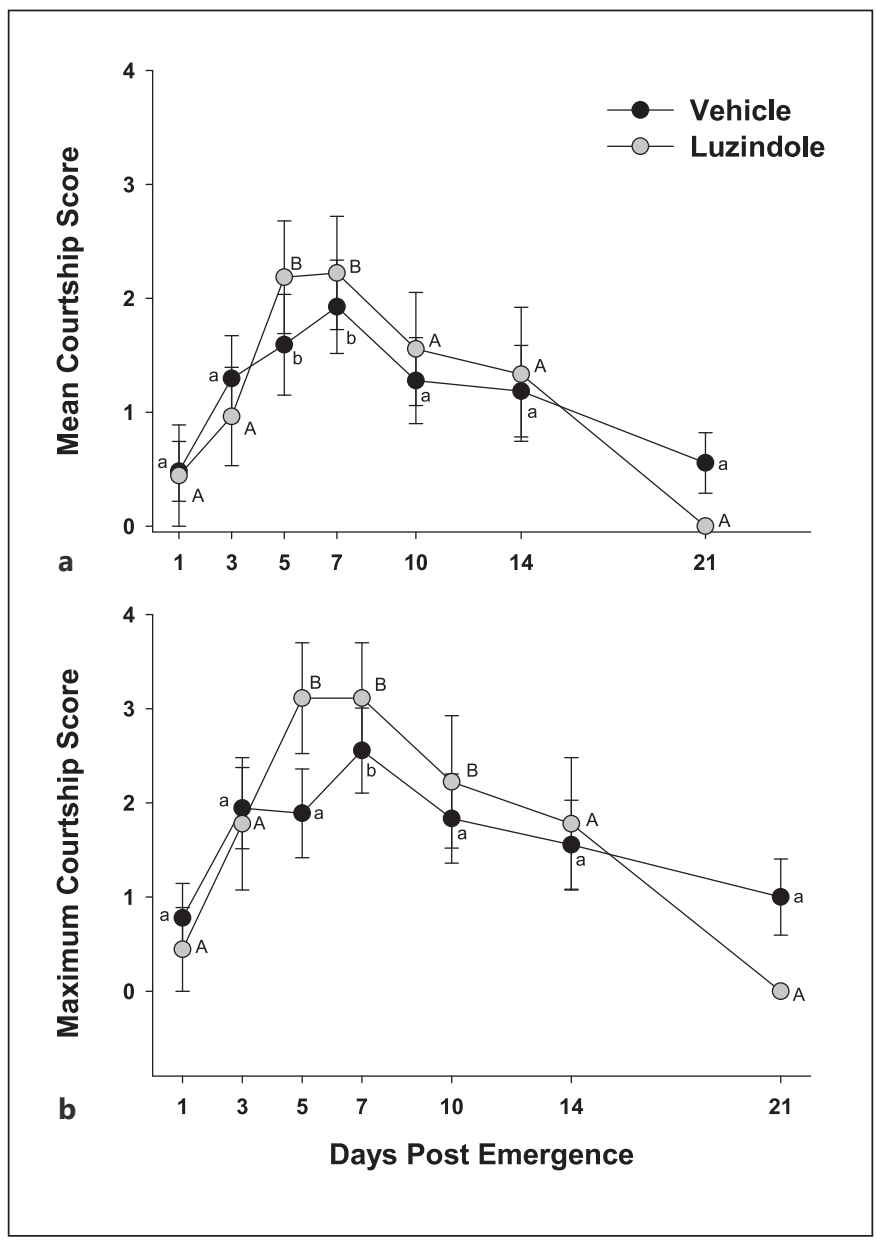

Fig. 7. Effect of treatment with vehicle $(n=18)$ and the melatonin receptor antagonist luzindole $(n=9)$ on the mean $(\mathbf{a})$ and maximum (b) courtship scores achieved by male red-sided garter snakes (Thamnophis sirtalis parietalis) following emergence from winter dormancy at $12^{\circ} \mathrm{C}$ for 6 weeks. Capital letters indicate significant differences between days post-emergence within the vehicle treatment group; lower-case letters indicate significant differences between days within the luzindole group. For both analyses, multiple-comparisons tests were performed by comparing each day post-emergence to day 1 (i.e., all pairwise comparisons were not performed to maintain statistical power). Data are the means \pm 1 SE.

For males hibernated at $12^{\circ} \mathrm{C}$ for 6 weeks, the main effects of luzindole versus vehicle treatment on mean courtship score were statistically nonsignificant $\left(F_{1,150}=0.0166\right.$, $p=0.899$, from a two-way repeated-measures ANOVA; Fig. 7a). However, mean courtship score varied significantly with days post-emergence $\left(F_{6,150}=8.048, p<0.001\right)$. The interaction between treatment and days post-emergence was statistically nonsignificant $\left(F_{6,150}=0.702, p=0.648\right)$. 
Similarly, while the main effects of luzindole treatment on courtship intensity (i.e., maximum courtship score) were statistically nonsignificant $\left(F_{1,150}=0.059, p=0.809\right.$; Fig. $7 b)$, we observed a significant change in maximum courtship score over days post-emergence $\left(F_{6,150}=9.337\right.$, $p<0.001$; Fig. $7 b)$. The interaction between treatment and days post-emergence was statistically nonsignificant $\left(F_{6,150}=1.510, p=0.179\right)$.

\section{Discussion}

It is now well established that photoperiod-induced changes in thyroid hormone metabolism within the hypothalamus mediate seasonal changes in the neuroendocrine reproductive axis (reviewed by [Nakane and Yoshimura, 2019]). Given the role of GnRH neurons in integrating multiple inputs with reproductive effort [e.g., Godwin, 2010; Stevenson et al., 2012; Maruska, 2014], we asked if environmental temperature also modulates hypothalamic thyroid hormone metabolism. How temperature cues are integrated with photoperiod information is relevant to all animals, but the impacts of temperature on seasonal reproduction are particularly critical to ectotherms. In red-sided garter snakes, for example, exposure to low temperatures $\left(4^{\circ} \mathrm{C}\right)$ for at least $3-8$ weeks is required to increase the expression of reproductive behavior (reviewed in [Lutterschmidt, 2012]). In a previous study, we found that exposure to low-temperature dormancy for 8-16 weeks increased both the number and size (a proxy for cell activity) of GnRH-ir neurons in male snakes [Lutterschmidt et al., 2022]. In this study, 6 weeks of dormancy at $4^{\circ} \mathrm{C}$ decreased TSH-ir cell number in the infundibulum but did not significantly alter Dio3 or GnRH immunoreactivity. The apparent discrepancy in $\mathrm{GnRH}$ between these studies is likely due to the shorter time-course and/ or repeated handling in the current study.

Because low-temperature dormancy increases GnRH-ir cell number in red-sided garter snakes, we predicted that TSH-ir cell number in the infundibulum would increase. In contrast to our prediction, we observed a significant decrease in the number of TSH-labeled cells. There are at least two possible explanations for these results. The first, related to a "release hypothesis," is that temperature-induced increases in TSH release from cells results in a decrease in TSH peptide stored within those cells. This subsequently results in fewer cells reaching the threshold of detection in immunohistochemistry and fewer positively labeled cells. Alternatively, it is possible that the decrease in TSH-ir cell number is related to the "resetting" of the sensitivity of the

Melatonin and Temperature-Induced

Changes in the Reproductive Axis reproductive axis to temperature cues. For example, a decrease in GnRH release and synthesis has been reported in photorefractory birds (reviewed in [MacDougall-Shackleton et al., 2009]). Majumdar et al. [2015] additionally provide evidence that elevated Dio3 expression may sustain the photorefractory state in redheaded buntings. Red-sided garter snakes exhibit similar refractoriness to warm temperatures; that is, exposure to low-temperature conditions is necessary to elicit responsiveness to warm temperatures and reproductive behavior during the spring (reviewed in [Lutterschmidt, 2012]). The observed decrease in TSH-ir cell number during the relatively early stages of low-temperature dormancy may, therefore, be related to the release of snakes from temperature refractoriness. A longer time course of low-temperature dormancy is required to assess which, if either, of these hypotheses explains the observed changes in TSH-ir cell number.

Relative to photoperiod, very few studies have investigated if and how environmental temperature impacts the neuroendocrine pathway that regulates changes in hypothalamic thyroid hormone metabolism and subsequent reproductive activity. Despite seeing few temperature-induced changes in this study, our results align with those available thus far. More specifically, the sensitivity to and influence of temperature on pars tuberalis TSH and/or hypothalamic thyroid hormone metabolism varies among taxa. In common voles (Microtus arvalis), photoperiod and temperature interact to regulate Dio $2 / 3$ expression, with warm temperatures $\left(21^{\circ} \mathrm{C}\right.$ vs. $\left.10^{\circ} \mathrm{C}\right)$ enhancing Dio2 expression and testosterone production during long days [Rosmalen et al., 2021]. However, pars tuberalis TSH expression was insensitive to temperature in voles. A similar enhancement in TSH, Dio2, and GnRH mRNA expression was observed in redheaded buntings (Emberiza bruniceps) housed under long-day conditions in combination with elevated temperatures $\left(38^{\circ} \mathrm{C}\right.$ vs. $22^{\circ} \mathrm{C}$ [Trivedi et al., 2019]). In the tropical spinefoot fish (Siganus guttatus), Dio2 expression in the mediobasal hypothalamus varied with the duration and phase of the photoperiod and decreased in response to melatonin treatment, but it was not significantly altered by water temperature [Wambiji et al., 2011]. Similar to known variation in the responses of both plants and animals to changing day length (e.g., differences in spring vs. fall breeders), how environmental temperature supplements other cues such as photoperiod, social stimuli, and food availability [e.g., Wambiji et al., 2011; Perfito et al., 2015] to regulate neural thyroid hormone metabolism likely varies with the ecology and life history of each species. 
Interestingly, comparative histological analyses reveal that in some groups of reptiles, including snakes, the pituitary pars tuberalis is reduced or absent altogether [Schreibman, 1986; Chester-Jones et al., 1987]. Despite this fact, we observed immunoreactive staining for TSH within the median eminence and infundibulum and in close proximity to where one might expect to find a pars tuberalis if it existed. We do not suggest from our immunohistochemical and histological analyses that garter snakes possess a distinct or even partial pars tuberalis. However, our results do indicate that a population of cells capable of producing TSH and responding to both temperature and treatment with 5-hydroxytryptophan resides within the pituitary stalk. Whether these cells exhibit other attributes of pars tuberalis cells is unknown, and it would be valuable to compare these results to other reptiles that do possess a distinct pars tuberalis (e.g., turtles and crocodiles). Further studies are also needed to identify the phenotype(s) of TSH-ir and Dio3-ir cells (e.g., ependymal versus other glial cells or neurons) and confirm the cellular location of staining (e.g., cytoplasm vs. nucleus). Nevertheless, our findings in garter snakes are supported by those of Nakane et al. [2013], who used masu salmon (Oncorhynchus masou masou) to demonstrate that fish, which also do not possess an anatomically distinct pars tuberalis, still exhibit the same characteristics of the photoperiodic regulatory center observed in birds and mammals. Specifically, in fish, this center is localized to the coronet cells of the saccus vasculosus, which both express TSH $\beta$ and deiodinases as well as respond to photoperiod information (but see also [Irachi et al., 2021]). Together, these results underscore the evolutionarily conserved nature of this pathway irrespective of whether a distinct pars tuberalis is present.

One question we sought to address in this research is whether the regulation of neural thyroid hormone metabolism in reptiles is more similar to birds or mammals. Although our data in garter snakes cannot provide a thorough test of this hypothesis (because we cannot assume that they represent the pattern found in other reptiles, including the ancestral reptiles that gave rise to birds), they do suggest that temperature-induced changes in TSH are sensitive to melatonin, as is the case in mammals. Male snakes treated with vehicle showed a significant decrease in TSH immunoreactivity within the infundibulum after 6 weeks of dormancy at $4^{\circ} \mathrm{C}$; this effect was reversed in males treated with the melatonin precursor 5-hydroxytryptophan. Although not statistically significant, treatment with 5 -hydroxytryptophan at $4^{\circ} \mathrm{C}$ also increased the number of Dio3-ir cells within the hypothala- mus $(p=0.084)$; increased levels of Dio3 result in degradation of thyroid hormones and are associated with reproductive quiescence [Nakane and Yoshimura, 2019]. Previous studies in garter snakes demonstrated that intraperitoneal injection of 5-hydroxytryptophan increases melatonin synthesis and circulating plasma melatonin concentrations [Lutterschmidt and Mason, 2010]. Together, these results indicate that TSH-ir cell number within the infundibulum is sensitive to low-temperature dormancy, and they additionally suggest that temperature-induced changes in TSH are mediated by decreased melatonin concentrations. Evidence that type 1a melatonin receptors are co-expressed within TSH-labeled cells in the infundibulum would support this conclusion.

As predicted, male snakes undergoing dormancy at an elevated temperature of $12^{\circ} \mathrm{C}$ for 6 weeks and treated with vehicle showed no change in TSH-ir, Dio3-ir, or GnRH-ir cell number. Inhibition of melatonin signaling via treatment with the melatonin receptor antagonist luzindole did not alter TSH- or Dio3-ir cell number. These results suggest that at elevated dormancy temperatures, inhibition of melatonin signaling is not sufficient in itself to mimic the effects of low-temperature dormancy. However, snakes treated with luzindole at $12^{\circ} \mathrm{C}$ showed a significant increase in $\mathrm{GnRH}$-ir cell number, suggesting that melatonin exerts an inhibitory effect on $\mathrm{GnRH}$ in garter snakes. However, these findings should be confirmed with additional studies, considering the increased mortality rate we observed among luzindole-treated snakes. Luzindole is a competitive melatonin receptor antagonist that has been shown to inhibit the effects of melatonin across a variety of species, including red-sided garter snakes [e.g., Dubocovich, 1988; Dubocovich et al., 1990; upubl. data]. While there is no indication in the literature or from our pilot studies that luzindole is cytotoxic, negative side effects of chronic exposure to luzindole at $12^{\circ} \mathrm{C}$ were apparent in this study. The negative impacts do not appear to result from a global increase in cellular processes, because luzindole treatment did not affect all of the variables included in this study.

Finally, we asked if observed changes in TSH, Dio3, and/or GnRH immunoreactivity are associated with changes in male courtship behavior. Several previous studies have documented the inhibitory effects of elevated melatonin, both endogenous and exogenous, on male courtship behavior (reviewed in [Lutterschmidt, 2012]). Further, male red-sided garter snakes hibernated at an elevated temperature $\left(10^{\circ} \mathrm{C}\right)$ had significantly higher plasma melatonin concentrations and also showed a significant delay in the onset of maximum courtship behav- 
ior [Lutterschmidt and Mason, 2009]. In the current study, both the mean and maximum courtship scores (measures of courtship endurance and intensity, respectively) of snakes maintained at $4^{\circ} \mathrm{C}$ and treated with 5-hydroxytryptophan declined significantly sooner after emergence compared to vehicle-treated snakes. These results suggest that the disruptive effects of elevated hibernation temperatures on courtship behavior are mediated through increased plasma melatonin concentrations, and these behavioral changes are concomitant with altered patterns of TSH immunoreactivity in the infundibulum. Of course, direct manipulations of TSH $\beta$ are needed to discern if and how it modulates seasonal changes in reproductive behavior and/or physiology. In contrast, males that were hibernated at $12^{\circ} \mathrm{C}$ and treated with vehicle or luzindole showed no significant differences in mean or maximum courtship scores upon emergence. Thus, we suggest that decreases in melatonin concentrations, which are observed in response to low-temperature dormancy, are not sufficient to override the effects of elevated winter dormancy temperatures on reproductive behavior. While the observed impacts on reproductive behavior may appear relatively minor, it should be noted that the mating season in northern populations of redsided garter snakes is extremely attenuated, and individual snakes can typically only sustain mate searching and courtship behavior for 5-14 days in this intense, scramble competition mating system [e.g., Lutterschmidt and Mason, 2008, 2009; this study]. Thus, any reduction or temporal shift in courtship behavior, however small, could have a disproportionately large impact on mating opportunities and reproductive fitness.

In summary, we found that 6 weeks of low-temperature dormancy at $4^{\circ} \mathrm{C}$ significantly decreased TSH-ir cell number in the infundibulum of the pituitary gland. Treatment of snakes with the melatonin precursor 5-hydroxytryptophan during dormancy at $4^{\circ} \mathrm{C}$ both eliminated the temperature-induced change in TSH immunoreactivity and disrupted the temporal pattern of male courtship behavior. Treatment of snakes with the melatonin receptor antagonist luzindole was not sufficient in rescuing the effects of dormancy at an elevated temperature $\left(12^{\circ} \mathrm{C}\right)$ on TSH immunoreactivity or courtship behavior. However, treatment with luzindole significantly increased GnRH-ir cell number within the hypothalamus of male snakes, providing evidence for an inhibitory effect of melatonin on $\mathrm{GnRH}$ peptide synthesis and/or release in vivo. Our results provide further evidence that the neuroendocrine pathway regulating photoperiod-induced changes in neural thyroid hormone metabolism is (1) modulated by en- vironmental temperature; (2) sensitive to changes in the hormone melatonin in a reptile; and (3) conserved among vertebrates, even in the absence of a well-developed pituitary pars tuberalis. Together, these results provide critical insights into the mechanisms that mediate the effects of temperature on reproductive physiology and behavior, information that is increasingly more imperative for understanding the impacts of our changing climate.

\section{Acknowledgements}

We would like to thank Kathleen Lynch and Blinda McClelland for the invitation to contribute to the symposium and this special issue of Brain, Behavior and Evolution in honor and in memory of Walt Wilczynski. D.I.L. is especially grateful to have had the opportunity to work with Walt and is thankful for all of the advice, lessons, and friendship he shared. We thank the Manitoba Department of Sustainable Development for permission to conduct these studies and Randy Krohmer for assistance with collecting snakes in the field. We thank Duncan MacKenzie and Stephen McCormick for insightful discussions about the comparative anatomy and physiology of pituitary glands. The following people assisted with various aspects of these experiments, and we are grateful for their help with animal care, injections, tissue sectioning, and immunohistochemistry assays: Eimy Aguado-Chavez, Bradley Cumez, Catherine Dayger, Alonso Delgado Covarrubias, Roslyn Honodel, Francine Iopu, Ashley Lucas, Christopher Lundrigan, Lauren Merlino, Benjamin Moore, Thu Nguyen, Kalera Stratton, Khahae Sutton, and Rachel Wilson. Portland State University's TRiO Upward Bound Program provided financial support to Eimy AguadoChavez and Thu Nguyen (both students at Franklin High School, Portland, OR, USA) during their Summer Research Internships.

\section{Statement of Ethics}

Experimental protocols were approved by the Portland State University Animal Care and Use Committee (approval number 59) and were in compliance with guidelines established by the National Institutes of Health Guide for the Care and Use of Laboratory Animals. This research was performed under the authority of Wildlife Scientific Permit WB18801 issued by the Manitoba Department of Sustainable Development.

\section{Conflict of Interest Statement}

The authors have no conflicts of interest to declare.

\section{Funding Sources}

This research was supported by a Forbes-Lea Graduate Student Research Grant from the Department of Biology at Portland State University awarded to T.J.W. and National Science Foundation grant IOS-1355203 awarded to D.I.L. 


\section{Author Contributions}

D.I.L. and T.J.W. designed and conducted the experiments. T.J.W. and S.M. processed tissues and performed the immunohistochemistry assays. S.M., H.A., and N.D.P. quantified the immunoreactive cell data. D.I.L. and T.J.W. analyzed and interpreted the data and wrote the paper.

\section{Data Availability Statement}

The data that support the findings of this study are available from the corresponding author upon reasonable request.

\section{References}

Ball GF, Ketterson ED. Sex differences in the response to environmental cues regulating seasonal reproduction in birds. Philos Trans R Soc Lond B Biol Sci. 2008 Jan 27;363(1490): 231-46.

Bona-Gallo A, Licht P. Effect of temperature on sexual receptivity and ovarian recrudescence in the garter snake, Thamnophis sirtalis parietalis. Herpetologica. 1983;39:173-82.

Boutin JA, Audinot V, Ferry G, Delagrange P. Molecular tools to study melatonin pathways and actions. Trends Pharmacol Sci. 2005; 26(8):412-9.

Chester-Jones I, Ingleton PM, Phillips JG, editors. Fundamentals of comparative vertebrate endocrinology. New York: Plenum Press; 1987.

Crews D, Camazine B, Diamond M, Mason R, Tokarz RR, Garstka WR. Hormonal independence of courtship behavior in the male garter snake. Horm Behav. 1984 Mar;18(1):29-41.

Dardente H. Does a melatonin-dependent circadian oscillator in the pars tuberalis drive prolactin seasonal rhythmicity? J Neuroendocrinol. 2007 Aug;19(8):657-66.

Dubocovich ML. Luzindole (N-0774): a novel melatonin receptor antagonist. J Pharmaco Exp Ther. 1988 Sep;246(3):902-10.

Dubocovich ML, Mogilnicka E, Areso PM. Antidepressant-like activity of the melatonin receptor antagonist, luzindole (N-0774), in the mouse behavioral despair test. Eur J Pharmacol. 1990 Jul 3;182(2):313-25.

Dubocovich ML, Rivera-Bermudez MA, Gerdin MJ, Masana MI. Molecular pharmacology, regulation and function of mammalian melatonin receptors. Front Biosci. 2003 Sep;8: d1093-108.

Garstka WR, Camazine B, Crews D. Interactions of behavior and physiology during the annual reproductive-cycle of the red-sided garter snake (Thamnophis sirtalis parietalis). Herpetologica. 1982;38(1):104-23.

Godwin J. Neuroendocrinology of sexual plasticity in teleost fishes. Front Neuroendocrinol. 2010 Apr;31(2):203-16.

Hanon EA, Lincoln GA, Fustin JM, Dardente H, Masson-Pevet M, Morgan PJ, et al. Ancestral TSH mechanism signals summer in a photoperiodic mammal. Curr Biol. 2008 Aug 5; 18(15):1147-52.

Ikemoto T, Park MK. Comparative analysis of the pituitary and ovarian GnRH systems in the leopard gecko: signaling crosstalk between multiple receptor subtypes in ovarian follicles. J Mol Endocrinol. 2007 Feb;38(1-2):289-304.
Irachi S, Hall DJ, Fleming MS, Maugars G, Björnsson BT, Dufour S, et al. Photoperiodic regulation of pituitary thyroid-stimulating hormone and brain deiodinase in Atlantic salmon. Mol Cell Endocrinol. 2021;519:111056.

Joseph SA, Knigge KM. Localization and content of TSH in median eminence of the hypothalamus. Am J Physiol. 1974 Mar;226(3):630-3.

Joy JE, Crews D. Social dynamics of group courtship behavior in male red-sided garter snakes (Thamnophis sirtalis parietalis). J Comp Psychol. 1985 Jun;99(2):145-9.

Juss TS, Meddle SL, Servant RS, King VM. Melatonin and photoperiodic time measurement in Japanese quail (Coturnix coturnix japonica). Proc Biol Sci. 1993 Oct 22;254(1339):218.

Krohmer RW, Boyle MH, Lutterschmidt DI, Mason RT. Seasonal aromatase activity in the brain of the male red-sided garter snake. Horm Behav. 2010 Aug;58(3):485-92.

Krohmer RW, Crews D. Temperature activation of courtship behavior in the male red-sided garter snake (Thamnophis sirtalis parietalis): role of the anterior hypothalamus-preoptic area. Behav Neurosci. 1987 Apr;101(2):22836.

Lutterschmidt DI. Chronobiology of reproduction in garter snakes: neuroendocrine mechanisms and geographic variation. Gen Comp Endocrinol. 2012 May 1;176(3):448-55.

Lutterschmidt DI, LeMaster MP, Mason RT. Effects of melatonin on the behavioral and hormonal responses of red-sided garter snakes (Thamnophis sirtalis parietalis) to exogenous corticosterone. Horm Behav. 2004 Dec;46(5): 692-702.

Lutterschmidt DI, LeMaster MP, Mason RT. Minimal over-wintering temperatures of redsided garter snakes: a possible cue for emergence? Can J Zool. 2006 Dec;44(6):722-22.

Lutterschmidt DI, Lucas AR, Summers AR. Trans-seasonal activation of the neuroendocrine reproductive axis: low-temperature winter dormancy modulates gonadotropinreleasing hormone neurons in garter snakes. J Exp Zool A Ecol Integr Physiol. 2022 Jan; 337(1):50-64

Lutterschmidt DI, Lutterschmidt WI, Hutchison $\mathrm{VH}$. Melatonin and thermoregulation in ectothermic vertebrates: a review. Can J Zool. 2003 Jan;81(1):1-13.

Lutterschmidt DI, Maine AR. Sex or candy? Neuroendocrine regulation of the seasonal transition from courtship to feeding behavior in male red-sided garter snakes (Thamnophis sirtalis parietalis). Horm Behav. 2014 Jun; 66(1):120-34.

Lutterschmidt DI, Mason RT. Geographic variation in timekeeping systems among three populations of garter snakes (Thamnophis sirtalis) in a common garden. Physiol Biochem Zool. 2008 Nov-Dec;81(6):810-25.

Lutterschmidt DI, Mason RT. Endocrine mechanisms mediating temperature-induced reproductive behavior in red-sided garter snakes (Thamnophis sirtalis parietalis). J Exp Biol. 2009 Oct 1;212(19):3108-18.

Lutterschmidt DI, Mason RT. Temporally distinct effects of stress and corticosterone on diel melatonin rhythms of red-sided garter snakes (Thamnophis sirtalis). Gen Comp Endocrinol. 2010 Oct;169(1):11-7.

Lutterschmidt DI, Wilczynski W. Sexually dimorphic effects of melatonin on brain arginine vasotocin immunoreactivity in green treefrogs (Hyla cinerea). Brain Behav Evol. 2012;80(3):222-32.

MacDougall-Shackleton SA, Stevenson TJ, Watts HE, Pereyra ME, Hahn TP. The evolution of photoperiod response systems and seasonal $\mathrm{GnRH}$ plasticity in birds. Integr Comp Biol. 2009;49(5):580-9.

Maine AR, Powers SD, Lutterschmidt DI. Seasonal variation in cell proliferation and cell migration in the brain of adult red-sided garter snakes (Thamnophis sirtalis parietalis). Brain Behav Evol. 2014;84(3):181-96.

Majumdar G, Rani S, Kumar V. Hypothalamic gene switches control transitions between seasonal life history states in a night-migratory photoperiodic songbird. Mol Cell Endocrinol. 2015 Jan 5;399:110-21.

Maruska KP. Social regulation of reproduction in male cichlid fishes. Gen Comp Endocrinol. 2014 Oct 1;207:2-12.

Morgan PJ, Williams LM. The pars tuberalis of the pituitary: a gateway for neuroendocrine output. Rev Reprod. 1996 Sep;1(3):153-61.

Nakane Y, Ikegami K, Iigo M, Ono H, Takeda K, Takahashi $\mathrm{D}$, et al. The saccus vasculosus of fish is a sensor of seasonal changes in day length. Nat Commun. 2013;4:2108.

Nakane Y, Yoshimura T. Photoperiodic regulation of reproduction in vertebrates. Annu Rev Anim Biosci. 2019 Feb 15;7:173-94.

Nakao N, Ono H, Yamamura T, Anraku T, Takagi T, Higashi K, et al. Thyrotrophin in the pars tuberalis triggers photoperiodic response. $\mathrm{Na}$ ture. 2008a Mar 20;452(7185):317-22. 
Nakao N, Ono H, Yoshimura T. Thyroid hormones and seasonal reproductive neuroendocrine interactions. Reproduction. 2008b Jul; 136(1):1-8.

Ono H, Hoshino Y, Yasuo S, Watanabe M, Nakane Y, Murai A, et al. Involvement of thyrotropin in photoperiodic signal transduction in mice. Proc Natl Acad Sci U S A. 2008 Nov 25;105(47):18238-42.

Perfito N, Guardado D, Williams TD, Bentley GE Social cues regulate reciprocal switching of hypothalamic Dio2/Dio3 and the transition into final follicle maturation in European starlings (Sturnus vulgaris). Endocrinology. 2015 Feb;156(2):694-706.

Perfito N, Jeong SY, Silverin B, Calisi RM, Bentley GE, Hau M. Anticipating spring: wild populations of great tits (Parus major) differ in expression of key genes for photoperiodic time measurement. PLoS One. 2012;7(4):e34997.

Pinillos ML, De Pedro N, Alonso-Gómez AL, Alonso-Bedate M, Delgado MJ. Food intake inhibition by melatonin in goldfish (Carassius auratus). Physiol Behav. 2001 Apr;72(5):62934.

Rosmalen L, Dalum J, Appenroth D, Roodenrijs RTM, Wit L, Hazlerigg DG, et al. Mechanisms of temperature modulation in mammalian seasonal timing. FASEB J. 2021;35(5):e21605.

Schreibman M. Pituitary gland. In: Pang P, Schreibman M, editors. Vertebrate endocrinology: fundamentals and biomedical implications. New York: Academic Press, Inc.; 1986. Vol. 1.
Smith MT, Moore FL, Mason RT. Neuroanatomical distribution of chicken-I gonadotropinreleasing hormone (cGnRH-I) in the brain of the male red-sided garter snake. Brain Behav Evol. 1997;49(3):137-48.

Stevenson TJ, Hahn TP, MacDougall-Shackleton SA, Ball GF. Gonadotropin-releasing hormone plasticity: a comparative perspective. Front Neuroendocrinol. 2012 Aug;33(3): 287-300.

Trivedi AK, Sur S, Sharma A, Taufique ST, Gupta NJ, Kumar V. Temperature alters the hypothalamic transcription of photoperiod responsive genes in induction of seasonal response in migratory redheaded buntings. Mol Cell Endocrinol. 2019 Aug;493:110454.

Unfried C, Ansari N, Yasuo S, Korf HW, von Gall C. Impact of melatonin and molecular clockwork components on the expression of thyrotropin beta-chain (Tshb) and the Tsh receptor in the mouse pars tuberalis. Endocrinology. 2009 Oct;150(10):4653-62.

Wambiji N, Park YJ, Kim SJ, Hur SP, Takeuchi Y, Takemura A. Expression of type II iodothyronine deiodinase gene in the brain of a tropical spinefoot, Siganus guttatus. Comp Biochem Physiol A Mol Integr Physiol. 2011 Dec; 160(4):447-52.

Weaver DR, Reppert SM. Melatonin receptors are present in the ferret pars tuberalis and pars distalis, but not in brain. Endocrinology. 1990 Nov;127(5):2607-9.

Whittier JM, Mason RT, Crews D, Licht P. Role of light and temperature in the regulation of reproduction in the red-sided garter snake, Thamnophis sirtalis parietalis. Can J Zool. 1987 Aug;65(8):2090-6.

Wood S, Loudon A. Clocks for all seasons: unwinding the roles and mechanisms of circadian and interval timers in the hypothalamus and pituitary. J Endocrinol. 2014 Aug;222(2): R39-59.

Yamamura T, Yasuo S, Hirunagi K, Ebihara S, Yoshimura T. T(3) implantation mimics photoperiodically reduced encasement of nerve terminals by glial processes in the median eminence of Japanese quail. Cell Tissue Res. 2006 Apr;324(1):175-9.

Yasuo S, Nakao N, Ohkura S, Iigo M, Hagiwara S, Goto A, et al. Long-day suppressed expression of type 2 deiodinase gene in the mediobasal hypothalamus of the Saanen goat, a short-day breeder: implication for seasonal window of thyroid hormone action on reproductive neuroendocrine axis. Endocrinology. 2006 Jan; 147(1):432-40.

Yasuo S, Watanabe M, Nakao N, Takagi T, Follett BK, Ebihara S, et al. The reciprocal switching of two thyroid hormone-activating and -inactivating enzyme genes is involved in the photoperiodic gonadal response of Japanese quail. Endocrinology. 2005 Jun;146(6):2551-4.

Yasuo S, Yoshimura T, Ebihara S, Korf HW. Photoperiodic control of TSH-beta expression in the mammalian pars tuberalis has different impacts on the induction and suppression of the hypothalamo-hypopysial gonadal axis. J Neuroendocrinol. 2009 Jan;22(1):43-50. 